Yazar Bilgileri

Ruşen Büken

Doktora Öğrencisi, Marmara Üniversitesi, Eğitim Bilimleri Enstitüsü,

rusenbuken@marun.edu.tr

\section{Eyüp Artvinli}

Prof. Dr., Eskişehir Osmangazi Üniversitesi, Eğitim Fakültesi, Türkçe ve Sosyal Bilimler Eğitimi, eartvinli@ogu.edu.tr

\section{Ruşen Büken, Eyüp Artvinli}

\section{ÖZ}

Bu araştırmanın amacı, ortaokul 6. ve 7. sınıf sosyal bilgiler ders kitaplarındaki coğrafya etkinliklerini Yenilenmiş Bloom Taksonomisi'ne göre analiz etmek ve karşılaştırmaktır. Çalışmada nitel araştırma yöntemlerinden doküman analizi kullanılmıştır. Araştırmanın veri kaynaklarını, Millî Eğitim Bakanlığı tarafından Tebliğler Dergisi'nin 2019 Aralık sayısında yayınlanan ve 2020-2021 eğitim-öğretim yllında okutulan özel ve MEB yayınlarına ait toplam beş adet olan 6 . ve 7. sınıf sosyal bilgiler ders kitapları içerisinde tespit edilen coğrafya etkinlikleri oluşturmaktadır. Veri kaynaklarını oluşturan söz konusu ders kitaplarındaki 340 coğrafya etkinliği Yenilenmiş Bloom Taksonomisi'nin bilişsel süreç basamaklarına göre incelenmiştir. İncelenen 340 coğrafya etkinliğinin 270 tanesinin hatırlama ve anlama basamağında olduğu sonucuna varılmıştır. Bu çalışmanın sonucuna göre sosyal bilgiler dersi kitaplarında yer verilen coğrafya etkinliklerinin programın hedeflediği üst bilişsel seviyeyi ölçen bir yaklaşımda olmadıkları tespit edilmiştir. Ders kitaplarının yazımında Yenilenmiş Bloom Taksonomisi'nin üst bilişsel düzey basamaklarını hedefleyen etkinliklere daha fazla yer verilmesi önerilmektedir. Böylece ortaokul öğrencilerinin coğrafi becerileri kazanmış bireyler olarak yetiştirilmesine imkân sağlanacağı düşünülmektedir.

\begin{tabular}{l}
\hline Makale Bilgileri \\
\hline Anahtar Kelimeler \\
Coğrafya Etkinliği \\
Sosyal Bilgiler Ders Kitapları \\
Yenilenmiş Bloom Taksonomisi
\end{tabular}

Keywords

Geography Activity

Social Studies Textbooks

Bloom's Revised Taxonomy

\section{Makale Geçmişi}

Geliş: 06.11.2021

Düzeltme: 24.11.2021

Kabul: 29.11.2021

\begin{abstract}
The purpose of this research is to analyze and compare the geography activities in the 6th and 7th grade social studies textbooks according to the Revised Bloom Taxonomy. Document analysis, one of the qualitative research methods, was used in the study. The data sources of the research consist of the geography activities determined in the 6th and 7th grade social studies textbooks, a total of five private and Ministry of National Education publications, published in the December 2019 issue of the Journal of Announcements by the Republic of Turkey MoNE and taught in the 2020-2021 academic year. A total of 340 geography activities in the textbooks that constitute the data sources were examined according to the cognitive process steps of the Revised Bloom Taxonomy. It was concluded that 270 of the 340 geography activities examined in the findings were at the remembering and understanding stages. According to the results of the study, it is seen that the geography activities in the textbooks are not aimed at the metacognitive level targeted by the curriculum. It is recommended to include more activities targeting the metacognitive levels of the Renewed Bloom Taxonomy in the writing of textbooks.
\end{abstract}

*Bu çalışma, ikinci yazar danışmanlığında birinci yazar tarafından yürütülen yüksek lisans tezinden üretilmiştir. 


\section{Giriş}

Öğrenme ortamlarında en çok kullanılan öğretim materyallerinden biri olan ders kitaplarının çağın eğitim anlayışını yakalaması beklenmektedir. Öğrencilerin en kolay ulaşabildiği materyal olması bakımından ders kitabının önemi büyüktür. Öğrenciye öğrenmesi gereken bilgileri, bireyi geliştirecek etkinlikleri ve neyi ne kadar öğrendiğini belirlemek amacı ile hazırlanmış değerlendirme sorularını içeren ders kitapları, eğitim için rehber niteliğindedir. Sosyoekonomik ve kültürel farklılıkları ayırt etmeden toplumun her kesimine ulaşması sebebiyle ders kitapları toplum için de büyük önem arz etmektedir (Ersoy ve Şahin, 2012).

MEB, ders kitaplarının yapılandırmacı yaklaşıma ve değişen Sosyal Bilgiler Dersi Öğretim Programları'na göre hazırlanması konusunda çalışmalar yapmış ve bu doğrultuda ders kitaplarında değişiklikler meydana gelmiştir (Altun, 2013; Kabapınar, 2019). Yapılandırmacı yaklaşıma göre yazılan ders kitaplarında, davranışçı yaklaşım ders kitaplarının aksine uzun, bilgiyi direkt sunan, tanımlarla dolu söz öbeklerine yer verilmemiştir (Kabapınar, 2019; Ocak ve Yurtseven, 2009; Önal ve Kaya, 2006).

Yapılandırmacı öğrenme anlayışında ürün ve süreci değerlendirme bakış açısı, ders kitaplarındaki etkinliklerin ve metinlerin işlenme şekilleriyle uygulamaya geçirilmektedir (Göçer, 2008). Ders kitaplarındaki etkinlikler öğrencide merak ve istek uyandırmalı ayrıca kitaplardaki sorular da üst düzey zihinsel becerileri içermelidir. Etkinliklerin uygulanabilir, ölçülebilir ve gözlenebilir olması gerekmektedir (Doğan ve Torun, 2018). Etkinlikler öğrencileri güdülemek, daha anlaşılır ve kalıcı öğrenmeyi sağlamak amacıyla kullanılmalı, aktif öğrenme ile önem kazanan etkinlikler yapılandırmacı yaklaşımın temel öğrenme aracı olmalıdır (Çevik ve Güneş, 2017). Ancak etkinliklerin organize edilmesi de kazanımlara bağlı olduğundan etkinlikleri kazanımlardan bağımsız olarak ele almak da zordur. Bu nedenle Sosyal Bilgiler Öğretim Programı'nda kazanımların çeşitli beceri ve değerlerle nasıl bir ilişkide olduğunun yanı sıra taksonomik düzeydeki ilişkisi de önemlidir (Artvinli ve Dönmez, 2020).

Yenilenmiş Bloom Taksonomisi (YBT); program geliştirme, öğretim etkinlikleri, öğretim programı kazanımları, ölçme değerlendirme gibi konular üzerine odaklanmıştır (Arı ve İnci, 2015; Beyreli ve Sönmez, 2017). Ders kitaplarında yer alan etkinliklerin Yenilenmiş Bloom Taksonomisi'ne göre incelendiği birçok çalışma mevcuttur (Can ve Ekim, 2020; Ulum, 2017; Usluoğlu, 2020). Öğrencinin pasif konumdan çıkıp yapılandırmacı yaklaşımla daha etkin hâle getirilmesiyle öğrenme esnasında neleri bildiği (bilgi boyutu) ve bunları nasıl (bilişsel süreç boyutları) öğrendiği önem kazanmıştır (Anderson vd., 2018). 


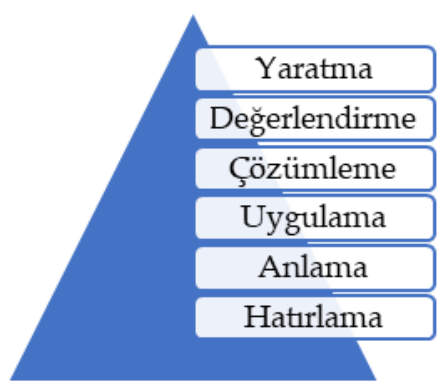

Şekil 1. Yenilenmiş Bloom Taksonomisi (YBT) Piramidi

Wilson, L. O. (2001). Anderson and Krathwohl Bloom's Taxonomy Revised understanding the new version of Bloom's taxonomy. https://quincycollege.edu/wp-content/uploads/Anderson-and-Krathwohl_ Revised-Blooms-Taxonomy.pdf sayfasından erişilmiştir.

Yenilenmiş Bloom Taksonomisi (YBT) bilişsel süreç sınıflandırmasında en basit bilişsel seviyeden başlayarak en karmaşık bilişsel seviyelere doğru gitmesi öngörülen bir öğrenme düzeni hâkimdir (Özdemir, Altıok ve Baki, 2015). Bu yaklaşımla derslerde yapılacak etkinliklerde öğrenci merkezde olacağı için hatırlama, anlama, uygulama, çözümleme, değerlendirme ve yaratma boyutlarını içeren bir ders akışı mümkün olmaktadır (Artvinli, 2010).

Bu araştırma, “Sosyal bilgiler ders kitaplarındaki coğrafya etkinliklerinin Yenilenmiş Bloom Taksonomisi'ndeki bilişsel süreç basamaklarına göre analizi nasıldır?" problem cümlesine göre yapılandırılmıştır. Bu sorunun amacı, 6. ve 7. sınıf sosyal bilgiler ders kitaplarındaki coğrafya etkinliklerini Yenilenmiş Bloom Taksonomisi'nin bilişsel süreç boyutuna göre analiz etmektir. Ortaokul sosyal bilgiler ders kitaplarındaki coğrafya etkinliklerinin taksonomik düzeyini analiz etmek için araştırmada cevap aranan alt problemler şunlardır:

1. 6. sınıf sosyal bilgiler ders kitaplarındaki coğrafya etkinliklerinin Yenilenmiş Bloom Taksonomisi'nin bilişsel süreç boyutu basamaklarına dağılımı nasıldır?

2. 7. sınıf sosyal bilgiler ders kitaplarındaki coğrafya etkinliklerinin Yenilenmiş Bloom Taksonomisi'nin bilişsel süreç boyutu basamaklarına dağılımı nasıldır?

\section{Yöntem}

$\mathrm{Bu}$ çalışmada nitel araştırma yaklaşımı kullanılmıştır. Nitel araştırma, gözlem, görüşme ve doküman analizi gibi nitel veri toplama yöntemlerinin kullanıldığı, algıların ve olayların doğal ortamda gerçekçi ve bütüncül bir biçimde ortaya konmasına yönelik nitel bir sürecin izlendiği araştırma olarak tanımlanabilir (Yıldırım ve Şimşek, 2018, s. 41). Araştırmada verilerin toplanması sürecinde doküman incelemesi tekniği kullanılmıştır. Araştırma konusuna uygun tüm belgeler doküman olarak kabul edilmektedir. Araştırmanın konusuyla ilgili tüm belgeleri incelemek araştırmacının görevidir (Karataş, 2015). Bu araştırma eğitim konulu bir çalışma olduğundan ders kitapları doküman incelemesinin kaynağını oluşturmaktadır. 
Veri toplamaya başlamadan önce konu hakkında literatür taranmış, bu kaynaklarda (Anderson vd., 2018; Arı, 2013; Bümen, 2006; Krathwohl, 2002; Ulum, 2017) hangi anahtar kelimelerin genel olarak hangi bilişsel beceri basamağına dâhil olduğu yazılı ve görsel materyaller incelenerek belirlenmeye çalışılmıştır. Kullanılan anahtar tabloya eklerde yer verilmiştir.

Araştırmanın veri kaynaklarını, Millî Eğitim Bakanlığı tarafından yayınlanan Tebliğler Dergisi'nin 2019 Aralık sayısında belirtilen 6. ve 7. sınıf sosyal bilgiler ders kitaplarındaki coğrafya etkinlikleri oluşturmaktadır. Sosyal bilgiler ders kitaplarında; 2018 Sosyal Bilgiler Öğretim Programı'nda yer alan "Birey ve Toplum", "Kültür ve Miras", "İnsanlar, Yerler ve Çevreler", "Bilim, Teknoloji ve Toplum”, “Üretim, Dağıtım ve Tüketim”, “Etkin Vatandaşlık” ve “Küresel Bağlantılar” öğrenme alanlarına yönelik yazılmış tüm konular incelenmiş ve coğrafya etkinliklerine sadece “Kültür ve Miras", "İnsanlar, Yerler ve Çevreler", “Üretim, Dağıtım ve Tüketim” ile "Küresel Bağlantılar" öğrenme alanına ait konularda rastlanmıştır. Ders kitaplarındaki etkinlikler, Yenilenmiş Bloom Taksonomisi'ne göre incelenerek karşılaştırma yapılmıştır. 6. ve 7. sınıf sosyal bilgiler ders kitaplarındaki coğrafya etkinlikleri, 2 coğrafya eğitimi uzmanı ile 1 sosyal bilgiler öğretmeninden görüş alınarak belirlenmiştir.

$\mathrm{Bu}$ araştırmada elde edilen dokümanlar betimsel analiz ile çözümlenmiştir. Betimsel analizde, araştırmanın veri kaynakları önceden belirlenmiş temalara göre incelenip yorumlanmaktadır. Bu incelemede doğrudan alıntılara sıklıkla yer verilmektedir (Yıldırım ve Şimşek, 2018, s. 239).

Millî Eğitim Bakanlığının 2019 yılı aralık sayısındaki Tebliğler Dergisi’nde belirlenen ve 20202021 eğitim-öğretim yılında okutulan beş adet sosyal bilgiler ders kitabındaki coğrafya etkinlikleri doküman incelemesine tabi tutulmuştur. Veri kaynaklarını oluşturan ders kitapları ve etkinlikler yorumlanırken kolaylık sağlanması açısından şu şekilde kodlanmıştır;

“6. Sınıf Sosyal Bilgiler Ders Kitabı, MEB Yayınları, 2019, 1. Bask1" = A1

“6. Sinıf Sosyal Bilgiler Ders Kitabı, Anadol Yayıncılık, 2019” = A2

“7. Sınıf Sosyal Bilgiler Ders Kitabı, MEB Yayınları, 2019, 2. Baskı” = B1

“7. Sinıf Sosyal Bilgiler Ders Kitabı, MEB Yayınları, 2019, 1. Baskı” = B2

“7. Sınıf Sosyal Bilgiler Ders Kitabı, Ekoyay Eğitim Yayıncılık, 2019“= B3

Sosyal bilgiler ders kitaplarında incelenen coğrafya etkinliklerinin ait olduğu öğrenme alanı şu şekilde kodlanmıştır;

Birey ve Toplum $=10 ̈ \mathrm{O}$

Kültür ve Miras = 2ÖA

İnsanlar, Yerler ve Çevreler $=30 ̈ \mathrm{~A}$ 
Bilim, Teknoloji ve Toplum = 4ÖA

Üretim, Dağıtım ve Tüketim = 5ÖA

Etkin Vatandaşlık = 6ÖA

Küresel Bağlantılar = 7ÖA

Sosyal bilgiler ders kitaplarında yer alan coğrafya etkinlileri şu şekilde kodlanmıştır;

Örnek Etkinlik Kodu: A1. 2ÖA. E3. şeklindedir.

A1: 6. sinif sosyal bilgiler ders kitabı

2ÖA: Etkinliğin bulunduğu Öğrenme Alanı (2. Öğrenme Alanı)

E3: Etkinlik sayısı (3. Etkinlik)

\section{Bulgular}

\section{Sınıf Sosyal Bilgiler Ders Kitaplarındaki Coğrafya Etkinliklerinin Yenilenmiş Bloom} Taksonomisi'nin Bilişsel Süreç Basamaklarına Dağılımı

Araştırmanın veri kaynaklarını oluşturan, Tebliğler Dergisi'nin 2019 yılı aralık sayısında adı yer alan 6. sınıf sosyal bilgiler ders kitapları incelenmiştir. Bu dönemde okullarda okutulmasına karar verilen iki tane ders kitabı bulunmaktadır. Bunlardan biri, Millî Eğitim Bakanlığına diğeri ise özel bir yayınevi olan Anadol Yayıncılık'a aittir. Bu ders kitapları detaylı bir şekilde incelenmiş ve tüm öğrenme alanlarına göre analiz edilmiştir. Kitapta yer alan coğrafya etkinlikleri Yenilenmiş Bloom Taksonomisi'nin bilişsel süreç basamaklarına göre analiz edilmiştir.

\section{Millı̂ Ĕ̆itim Bakanlı̆̆ına Ait 6. Sınıf Sosyal Bilgiler Ders Kitabı (A1):}

Bu aşamada Millî Eğitim Bakanlığına ait 6. sınıf sosyal bilgiler ders kitabı incelenmiştir. Ders kitaplarında coğrafya etkinliği olarak tespit edilen 68 tane etkinliğin Yenilenmiş Bloom Taksonomisi'nin bilişsel süreç basamaklarına göre dağılımı Tablo 1'de verilmiştir.

Tablo 1. 6. Sınıf Sosyal Bilgiler Ders Kitabı'nın (MEB Yayınları) Yenilenmiş Bloom Taksonomisi'nin Bilişsel Süreç Basamaklarına Dağılımı

\begin{tabular}{|c|c|c|c|c|c|}
\hline & $\begin{array}{l}\text { Kültür ve } \\
\text { Miras }\end{array}$ & $\begin{array}{l}\text { Insanlar, } \\
\text { Yerler ve } \\
\text { Çevreler }\end{array}$ & $\begin{array}{c}\text { Üretim, } \\
\text { Dağıttm ve } \\
\text { Tüketim }\end{array}$ & $\begin{array}{c}\text { Küresel } \\
\text { Bă̆lantılar }\end{array}$ & Toplam \\
\hline Hatırlama & 3 & 4 & 9 & 4 & 20 \\
\hline Anlama & 6 & 18 & 7 & 7 & 38 \\
\hline Uygulama & 1 & 1 & 1 & - & 3 \\
\hline Çözümleme & 1 & 1 & - & 4 & 6 \\
\hline Değerlendirme & - & - & - & - & - \\
\hline Yaratma & - & - & 1 & - & 1 \\
\hline Toplam Etkinlik & 11 & 24 & 18 & 15 & 68 \\
\hline
\end{tabular}


Ders kitabının tamamı incelenmiş ve coğrafya etkinliklerinin "Kültür ve Miras", "İnsanlar, Yerler ve Çevreler", “Üretim, Dağıtım ve Tüketim” ve "Küresel Bağlantılar" öğrenme alanlarında olduğu görülmüştür. Toplam 68 etkinlik incelendiğinde coğrafya konularındaki en fazla etkinliğin insanlar, yerler ve çevreler öğrenme alanında olduğu, en az coğrafya etkinliğinin ise kültür ve miras öğrenme alanında olduğu görülmüştür. Bu etkinliklerin 20 tanesi hatırlama basamağında, 38 tanesi anlama basamağında, 3 tanesi uygulama basamağında 6 tanesi çözümleme basamağında 1 tanesi ise yaratma basamağındadır. Değerlendirme basamağında coğrafya etkinliğinin olmadığı görülmüştür. Örneğin;

Etkinlik Kodu: A1.3ÖA.E3

Bilişsel Süreç Basamağı: Hatırlama

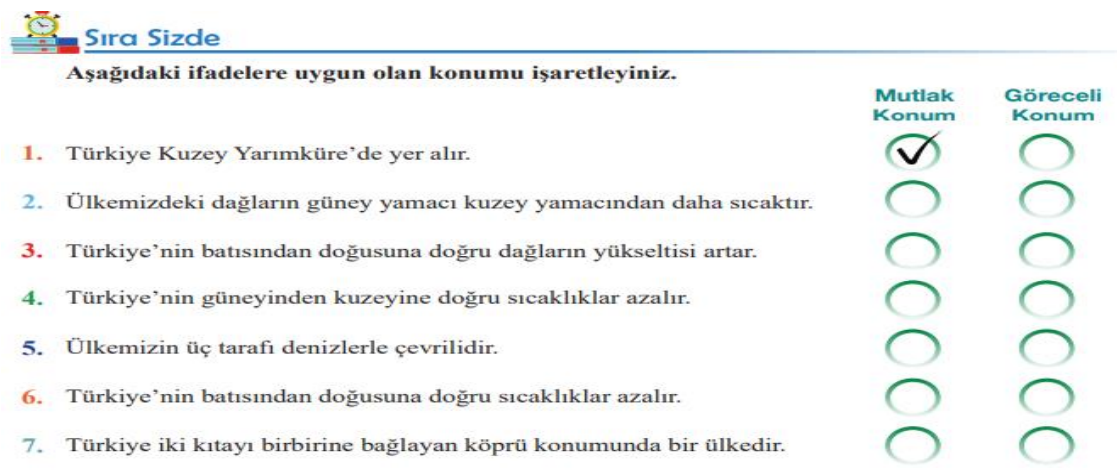

Şekil 2. A1.3ÖA.E3 Kodlu Etkinlik (A1, s. 110)

A1 kodlu MEB 6. sınıf sosyal bilgiler ders kitabının İnsanlar, Yerler ve Çevreler öğrenme alanında yer alan etkinlikte öğrenciye daha önce verilmiş olan bilgilerin öğrenci tarafından hatırlanması ve doğrudan söylenip ders kitabındaki ait olduğu yere işaretlenmesi beklenmektedir. Şekil 2'de yer alan bu etkinlik Yenilenmiş Bloom Taksonomisi'nin en alt bilişsel süreç basamağı olan hatırlama basamağına yerleştirilmiştir.

Etkinlik Kodu: A1.2ÖA.E7

Bilişsel Süreç Basamağı: Uygulama

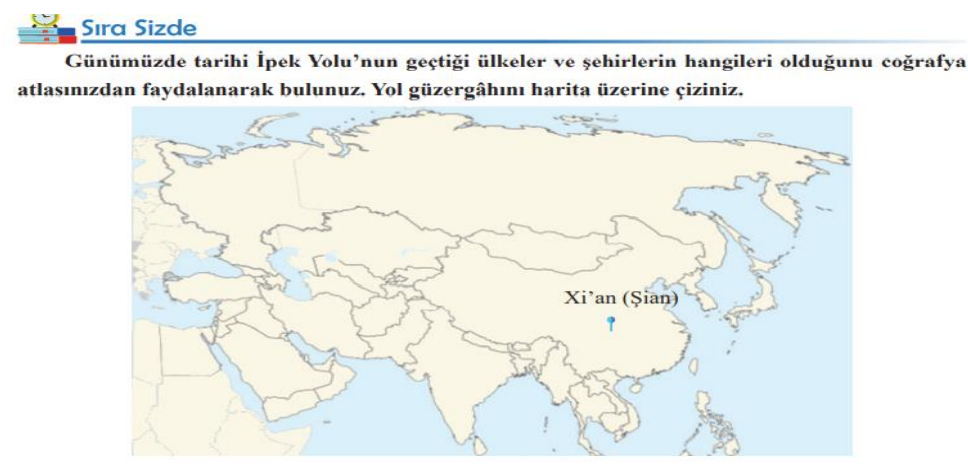

Şekil 3. A1.2ÖA.E7 Kodlu Etkinlik (A1, s. 96) 
A1 kodlu MEB 6. sınıf sosyal bilgiler ders kitabının Kültür ve Miras öğrenme alanında yer alan bu etkinlikte öğrencilerden önceki deneyimlerine dayanarak yeni bir işlemi yerine getirmesi beklenmektedir. Verilen coğrafya etkinliğinde, öğrencinin harita üzerine daha önce öğrendiği İpek Yolu güzergahında bulunan şehir ve ülkeleri çizmesi Yenilenmiş Bloom Taksonomisi'ndeki uygulama basamağına işaret etmektedir.

\section{Anadol Yayıncılık'a Ait 6. Sınıf Sosyal Bilgiler Ders Kitabı (A2):}

Bu aşamada Anadol Yayıncılık'a ait olan 6. sınıf sosyal bilgiler ders kitabındaki coğrafya konulu etkinlikler Yenilenmiş Bloom Taksonomisi'nin bilişsel süreç basamağına göre incelenmiştir.

Tablo 2. Anadol Yayıncılık 6. Sınıf Sosyal Bilgiler Ders Kitabı Yenilenmiş Bloom Taksonomisi'nin Bilişsel Süreç Basamaklarına Dağılımı

\begin{tabular}{lccccc}
\hline & $\begin{array}{c}\text { Kültür ve } \\
\text { Miras }\end{array}$ & $\begin{array}{c}\text { Insanlar, } \\
\text { Yerler ve } \\
\text { Çevreler }\end{array}$ & $\begin{array}{c}\text { Üretim, } \\
\text { Dă̆ıtım ve } \\
\text { Tüketim }\end{array}$ & $\begin{array}{c}\text { Küresel } \\
\text { Bă̆lantılar }\end{array}$ & Toplam \\
\hline Hatırlama & 1 & 5 & 3 & 3 & 12 \\
Anlama & 2 & 17 & 7 & 2 & 28 \\
Uygulama & 1 & 1 & - & 1 & 3 \\
Çözümleme & 1 & - & 2 & - & 3 \\
Değerlendirme & - & 1 & 1 & 3 & 5 \\
Yaratma & - & - & 1 & - & 52 \\
\hline Toplam Etkinlik & 5 & 24 & 14 & 9 & 52 \\
\hline Şahin, E. (2019). Ortaokul ve imam hatip ortaokulu 6. sinff sosyal bilgiler ders kitabı. Ankara: Anadol Yayıncilik.
\end{tabular}

İlgili ders kitabının tamamı incelenmiş ve coğrafya etkinliklerinin Kültür ve Miras, İnsanlar, Yerler ve Çevreler, Üretim, Dağıtım ve Tüketim ile Küresel Bağlantılar öğrenme alanlarında olduğu görülmüştür. Toplam 52 etkinliğin incelendiği bu kitapta en çok coğrafya etkinliğinin insanlar, yerler ve çevreler öğrenme alanında olduğu, en az coğrafya etkinliğinin ise kültür ve miras öğrenme alanında olduğu belirlenmiştir. Toplamda 12 hatırlama basamağı, 28 anlama basamağı, 3 uygulama basamağı, 3 çözümleme basamağı, 5 değerlendirme basamağı ve 1 yaratma basamağı etkinliği bulunmaktadır. Alt düzey düşünme becerilerine ait etkinliklerin yoğunlukta olduğu görülmektedir. Örneğin;

Etkinlik Kodu: A2.5ÖA.E7

Bilişsel Süreç Basamağı: Anlama

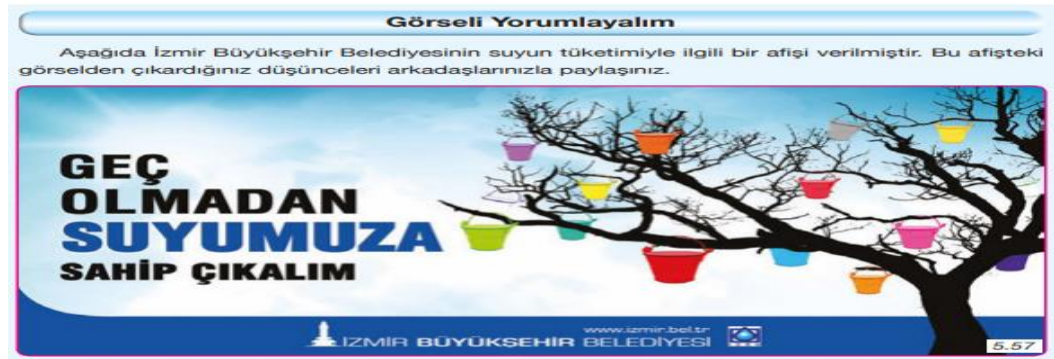

Şekil 4. A2.5ÖA.E7 Kodlu Etkinlik (A2, s. 171) 
Anadol Yayıncılık'a ait 6. sınıf sosyal bilgiler ders kitabındaki Üretim, Dağıtım ve Tüketim öğrenme alanında yer alan bu etkinlikte, öğrencinin verilen görseli yorumlaması ve çıardığı anlamları açıklaması beklenmektedir. Ders kitabında verilen bu etkinlik Yenilenmiş Bloom Taksonomisi'nin bilişsel süreç basamaklarından anlama basamağına karşılık gelmektedir.

Etkinlik Kodu: A2.2ÖA.3E

Bilişsel Süreç Basamağı: Çözümleme

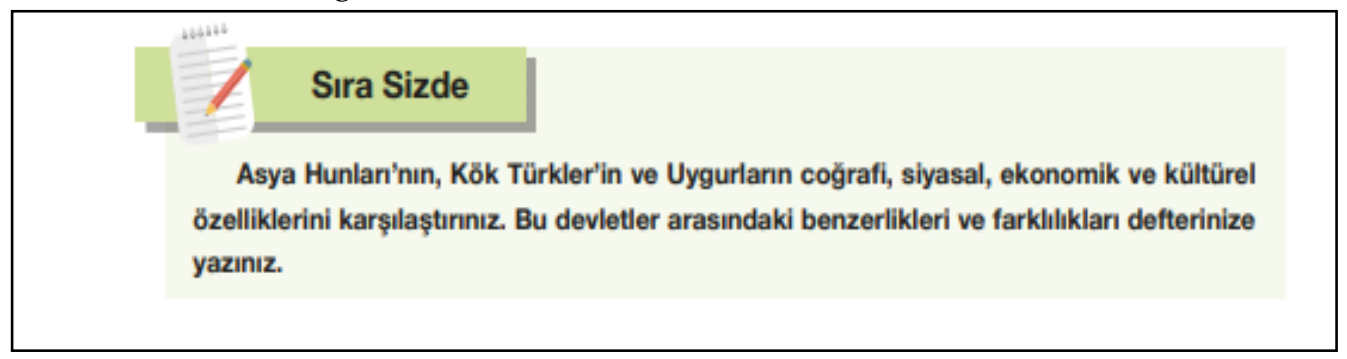

Şekil 5.A2.2ÖA.3E Kodlu Etkinlik (A2, s. 47)

Anadol Yayıncılık'a ait olan 6. sınıf sosyal bilgiler ders kitabındaki Kültür ve Miras öğrenme alanında yer alan bu etkinlikte öğrenciden verilen devletler arasında bağ kurması, kıyaslama yapması, bu devletleri farklı kategoriler altında irdelemesi istenilmiştir. Etkinlikte öğrenciden beklenen beceriler göz önüne alındığında etkinliğin Yenilenmiş Bloom Taksonomisi'nin çözümleme basamağına uygun olduğu kararına varılmıştır.

6. sınıfa ait her iki ders kitabında yer alan coğrafya etkinliklerinin YBT'nin bilişsel süreç basamaklarına dağılımı Şekil 6'da karşılaştırmalı olarak verilmiştir.

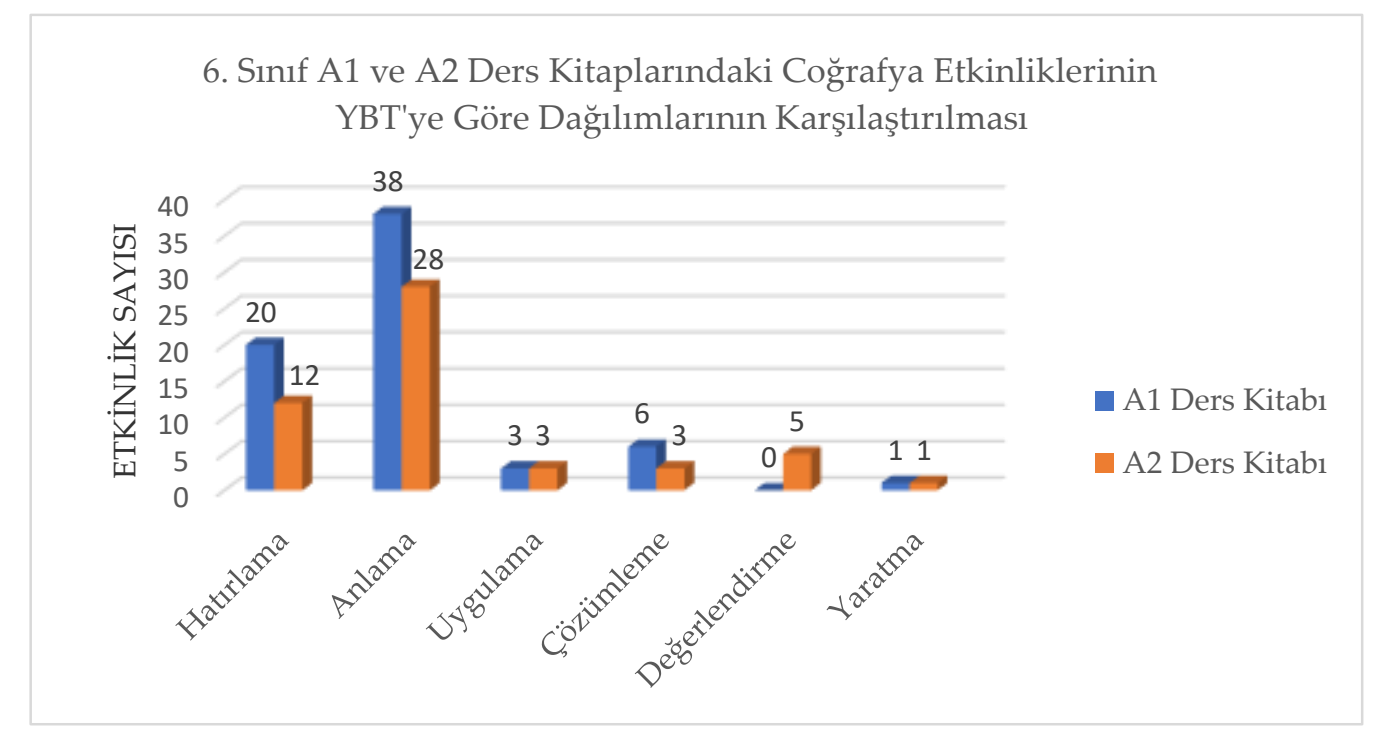

Şekil 6. A1 ve A2 Ders Kitaplarındaki Coğrafya Etkinliklerinin YBT’ye Göre Dağılımlarının Karşılaştırılması 


\section{Sınıf Sosyal Bilgiler Ders Kitaplarındaki Coğrafya Etkinliklerinin Yenilenmiş Bloom}

\section{Taksonomisi'nin Bilişsel Süreç Basamaklarına Dağılımı}

$\mathrm{Bu}$ aşamada araştırmanın veri kaynakları içinde yer alan 7. sınıf sosyal bilgiler ders kitapları incelenmiştir. 2019 yılı aralık sayısında yayınlanan Tebliğler Dergisine göre 7. sınıflara ait üç tane ders kitabı bulunmaktadır. Bunlardan ikisi, Millî Eğitim Bakanlığına, bir tanesi ise özel bir yayınevi olan Ekoyay Yayıncılık'a aittir. Ders kitaplarının tüm öğrenme alanları incelenmiş ve coğrafi konulara ait olduğu belirlenen etkinlikler Yenilenmiş Bloom Taksonomisi'nin bilişsel süreç basamaklarına göre analiz edilmiştir. Her üç kitabın analizinden sonra coğrafya etkinlikleri karşılaştırılmış ve tek tabloda sunulmuştur.

\section{Millî Ĕ̆itim Bakanlı̆̆ına Ait 7. Sınıf Sosyal Bilgiler Ders Kitabı (B1):}

Millî Eğitim Bakanlığına ait 7. sınıf sosyal bilgiler ders kitabının tamamı incelenmiştir. Bu ders kitabında yer alan coğrafya etkinliklerinin Yenilenmiş Bloom Taksonomisi'nin bilişsel süreç basamaklarına göre dağılımı Tablo 3'te verilmiştir.

Tablo 3. MEB Yayınları 7. Sınıf Sosyal Bilgiler Ders Kitabı'nın Yenilenmiş Bloom Taksonomisi'nin Bilişsel Süreç Basamaklarına Dağılımı

\begin{tabular}{|c|c|c|c|c|c|}
\hline & $\begin{array}{c}\text { Kültür ve } \\
\text { Miras }\end{array}$ & $\begin{array}{l}\text { Insanlar, } \\
\text { Yerler ve } \\
\text { Çevreler }\end{array}$ & $\begin{array}{c}\text { Üretim, } \\
\text { Dağıtım ve } \\
\text { Tüketim }\end{array}$ & $\begin{array}{c}\text { Küresel } \\
\text { Bağlantılar }\end{array}$ & Toplam \\
\hline Hatırlama & 5 & 9 & 5 & 2 & 21 \\
\hline Anlama & 3 & 10 & 4 & 3 & 20 \\
\hline Uygulama & - & - & 1 & - & 1 \\
\hline Çözümleme & - & 1 & - & - & 1 \\
\hline Değerlendirme & 2 & 1 & 1 & 3 & 7 \\
\hline Yaratma & - & - & 1 & 2 & 3 \\
\hline Toplam Etkinlik & 10 & 21 & 12 & 10 & 53 \\
\hline
\end{tabular}

Millı̂ Eğitim Bakanlığına ait 7. sınıf sosyal bilgiler ders kitabı incelenmiş ve coğrafya etkinliklerine "Kültür ve Miras", "İnsanlar, Yerler ve Çevreler", "Üretim, Dağıtım ve Tüketim" ile "Küresel Bağlantılar" öğrenme alanlarında rastlanmıştır. Toplam 53 coğrafya etkinliğinin bulunduğu bu kitapta 21 tane hatırlama basamağına, 20 tane anlama basamağına, 1 tane uygulama basamağına, 1 tane çözümleme basamağına, 7 tane değerlendirme ve 3 tane de yaratma basamağına ait etkinlik bulunmaktadır. Etkinliklerin alt düzey düşünme becerilerini geliştirmeye yönelik olduğu tespit edilmiştir. En çok coğrafya etkinliğinin insanlar, yerler ve çevreler öğrenme alanında olduğu belirlenmiştir. En az coğrafya etkinliği ise kültür ve miras ile küresel bağlantılar öğrenme alanlarında yer almaktadır. Örneğin;

Etkinlik Kodu: B1.3ÖA.E13 
Bilişsel Süreç Basamağı: Değerlendirme
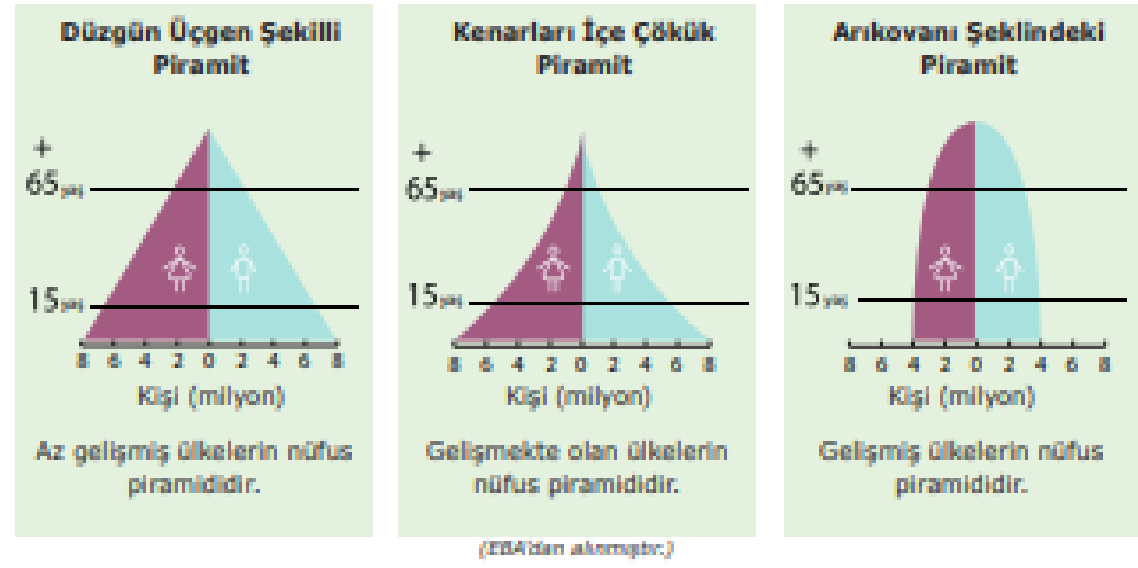

Ôlemizin 1935-1980-2017 ncfus piramitleri şu şekildedir.

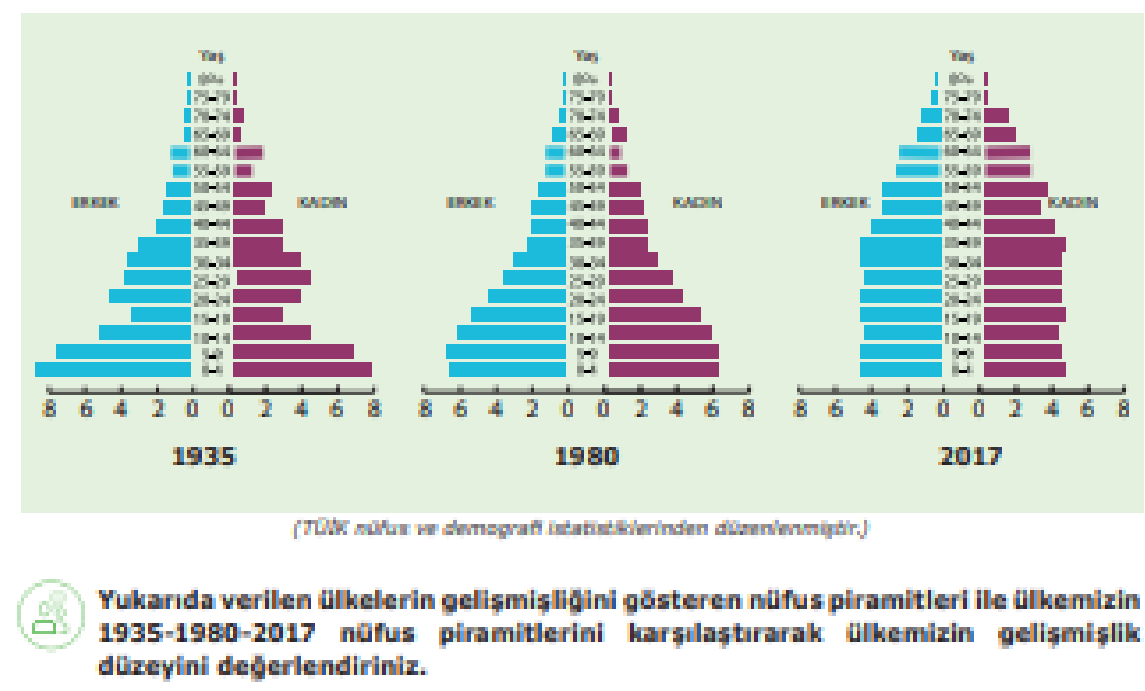

Şekil 7. B1.3ÖA.E13 Kodlu Etkinlik (B1, s. 109)

B1 kodlu 7. sınıf sosyal bilgiler ders kitabının insanlar, yerler ve çevreler öğrenme alanında yer alan bu coğrafya etkinliğinde öğrencinin verilen nüfus piramitlerini az gelişmiş, gelişmekte olan ve gelişmiş ülkelerin nüfus piramitlerini baz alarak değerlendirmesi beklenmektedir. Verilen belirli bir ölçüte göre öğrencinin karar vermesi istendiğinden bu coğrafya etkinliği YBT'nin bilişsel basamaklarından değerlendirme basamağına yerleştirilmiştir.

\section{Millî Ĕ̆itim Bakanlı̆̆ına Ait 7. Sınıf Sosyal Bilgiler Ders Kitabı (B2):}

Bu aşamada Millî Eğitim Bakanlığına ait B2 kodlu 7. sınıf sosyal bilgiler ders kitabı incelenmiştir. Bu ders kitabında yer alan coğrafya etkinliklerinin Yenilenmiş Bloom Taksonomisi'nin bilişsel süreç basamaklarına göre dağılışı Tablo 4'te gösterilmiştir. 
Tablo 4. MEB Yayınları 7. Sınıf Sosyal Bilgiler Ders Kitabı'nın Yenilenmiş Bloom Taksonomisi'nin Bilişsel Süreç Basamaklarına Dağılımı

\begin{tabular}{lccccc}
\hline & $\begin{array}{c}\text { Kültür ve } \\
\text { Miras }\end{array}$ & $\begin{array}{c}\text { Insanlar, } \\
\text { Yerler ve } \\
\text { Çevreler }\end{array}$ & $\begin{array}{c}\text { Üretim, } \\
\text { Dağıtım ve } \\
\text { Tüketim }\end{array}$ & $\begin{array}{c}\text { Küresel } \\
\text { Bağlantılar }\end{array}$ & Toplam \\
\hline Hatırlama & 3 & 9 & 8 & - & 20 \\
Anlama & 3 & 27 & 9 & 6 & 45 \\
Uygulama & - & 2 & 3 & 4 & 9 \\
Çözümleme & - & - & - & 2 & 2 \\
Değerlendirme & - & - & - & 4 & 4 \\
Yaratma & - & - & - & 1 & 1 \\
\hline Toplam Etkinlik & 6 & 38 & 20 & 17 & 81 \\
\hline Açl, Ö., Güvenç, H., Hayta, A. \& K1lıç, S. (2019). Ortaokul ve imam hatip ortaokulu 7. sinıf sosyal bilgiler \\
ders kitabı. Ankara: MEB Yayınları, [e-kitap sürümü]. https://ders.eba.gov.tr/ders/proxy/VCollabPlayer \\
v0.0.816/index.html\#/main/dashboard/3/1/0 sayfasından erişilmiştir.
\end{tabular}

Millî Eğitim Bakanlığına ait 7. sınıf sosyal bilgiler ders kitabı (B2) incelenmiş ve coğrafya etkinliklerine Kültür ve Miras, İnsanlar, Yerler ve Çevreler, Üretim, Dağıtım ve Tüketim ile Küresel Bağlantılar öğrenme alanlarında rastlanmıştır. Toplam 81 coğrafya etkinliği incelenmiştir. En çok etkinlik insanlar, yerler ve çevreler öğrenme alanına aittir. Bu ders kitabında toplamda 20 hatırlama basamağı, 45 anlama basamağı, 9 uygulama basamağı, 2 çözümleme basamağı, 4 değerlendirme basamağı ve 1 yaratma basamağı etkinliği yer almıştır. Üst düzey bilişsel becerilere ait etkinlikler sadece küresel bağlantılar öğrenme alanında tespit edilmiştir. En alt basamak olan hatırlama basamağı küresel bağlantılar öğrenme alanında yer almamıştır.

Etkinlik Kodu: B2.2ÖA.E2

Bilişsel Süreç Basamağı: Hatırlama

\section{BIRLIKTE YAPIYORUZ}

İspanyol ve Portekizli gemicilerin keşfettikleri yerleri aşağıdaki bölümlere işaretleyiniz.

\begin{tabular}{|l|l|l|l|}
\hline \multicolumn{1}{|c|}{ Kaşifler } & Ümit Burnu & Amerika & Hindistan \\
\hline Bartolomeu Dias & & & \\
\hline Vasco Da Gama & & & \\
\hline Kristof Kolomb & & \\
\hline
\end{tabular}

Şekil 8. B2.2ÖA.E2 Kodlu Etkinlik (B2, s. 66)

B2 kodlu 7. sınıf ders kitabının kültür ve miras öğrenme alanında yer alan bu etkinlikte, öğrencilerden; kâşiflerin keşfettikleri yerleri bilip işaretlemeleri istenmiştir. Bilme, ezberleme, yerini tespit etme becerilerinin hedeflendiği bu etkinlik YBT'nin hatırlama basamağına seçilmiştir.

Etkinlik Kodu: B2. 7ÖA. E15

Bilişsel Süreç Basamağı: Yaratma 


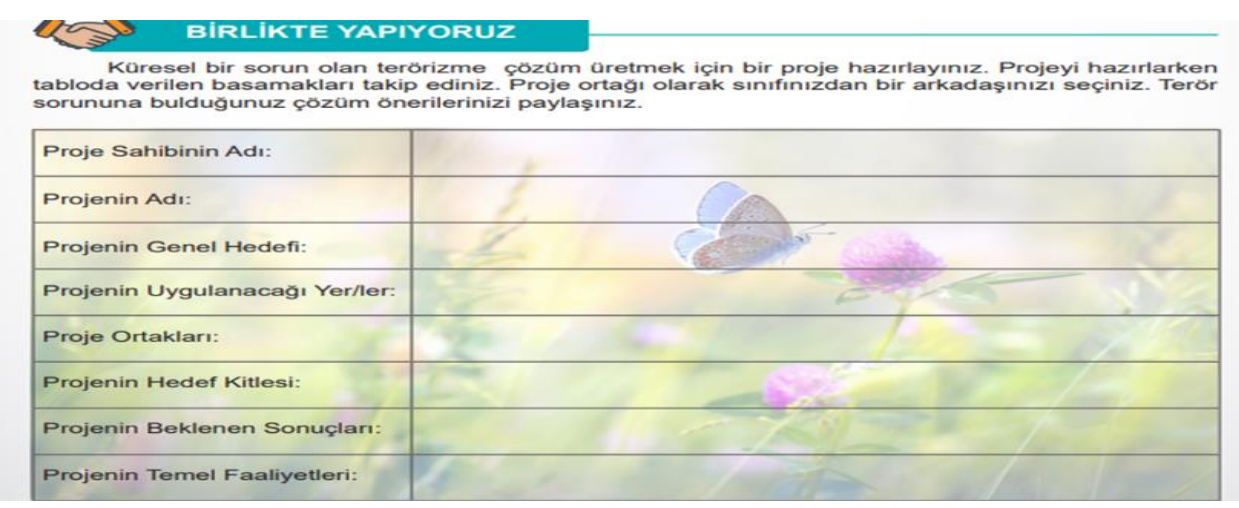

Şekil 9. B2. 7ÖA. E15 Kodlu Etkinlik (B2, s. 217)

B2 kodlu 7. sınıf sosyal bilgiler ders kitabında verilen bu etkinlikte, öğrenciden küresel sorunlara yönelik bir proje geliştirmesi beklenmiştir. Öğrenciden, sınıf arkadaşıyla müzakere edip birlikte çalışması istenmektedir. Plan yapıp bir fikri hayata geçirme üzerine kurulmuş olan bu etkinlik YBT'nin yaratma bilişsel basamağına seçilmiştir.

\section{Ekoyay Yayınlarına Ait 7. Sinıf Sosyal Bilgiler Ders Kitabı (B3):}

Ekoyay Yayınlarına ait ders kitabındaki coğrafya etkinlikleri Yenilenmiş Bloom Taksonomisi'nin bilişsel süreç basamağına göre incelenmiştir. Bulgular Tablo 5'te verilmiştir.

Tablo 5. Ekoyay Yayıncılık 7. Sınıf Sosyal Bilgiler Ders Kitabı'nın Yenilenmiş Bloom Taksonomisinin Bilişsel Süreç Basamaklarına Göre Dağılımı

\begin{tabular}{lccccc}
\hline & Kültür ve Miras & $\begin{array}{c}\text { Insanlar, Yerler } \\
\text { ve Çevreler }\end{array}$ & $\begin{array}{c}\text { Üretim, } \\
\text { Dă̆ıtım ve } \\
\text { Tüketim }\end{array}$ & $\begin{array}{c}\text { Küresel } \\
\text { Bağlantılar }\end{array}$ & Toplam \\
\hline Hatırlama & 2 & 7 & 6 & 14 & 29 \\
Anlama & 5 & 17 & 9 & 6 & 37 \\
Uygulama & - & 5 & 2 & - & 7 \\
Çözümleme & 1 & 2 & 1 & 3 & 4 \\
Değerlendirme & - & - & - & 2 & 2 \\
Yaratma & - & - & - & 29 & 86 \\
\hline Toplam Etkinlik & 8 & 31 & 18 & 4 & 7 \\
\hline
\end{tabular}

Azer, H. (2019). Ortaokul ve imam hatip ortaokulu 7. sınıf sosyal bilgiler ders kitabı. Ankara: Ekoyay Eğitim Yayıncılık.

Ekoyay Yayıncılık'a ait olan 7. sınıf sosyal bilgiler ders kitabının tamamı incelenmiş ve coğrafya etkinliklerine kültür ve miras, insanlar, yerler ve çevreler, üretim, dağıtım ve tüketim ve küresel bağlantılar öğrenme alanlarında rastlanmıştır. Toplam 86 coğrafya etkinliğinin incelendiği bu kitapta en çok coğrafya etkinliği insanlar, yerler ve çevreler öğrenme alanında bulunmaktadır.

En az etkinlik ise kültür ve miras öğrenme alanında yer almaktadır. 29 hatırlama basamağı, 37 anlama basamağı, 7 uygulama basamağı, 7 çözümleme basamağı, 4 değerlendirme basamağı ve 2 yaratma basamağına ait coğrafya etkinliği bulunmaktadır. Örneğin;

Etkinlik Kodu: B3.3ÖA.E24

Bilişsel Süreç Basamağı: Uygulama 


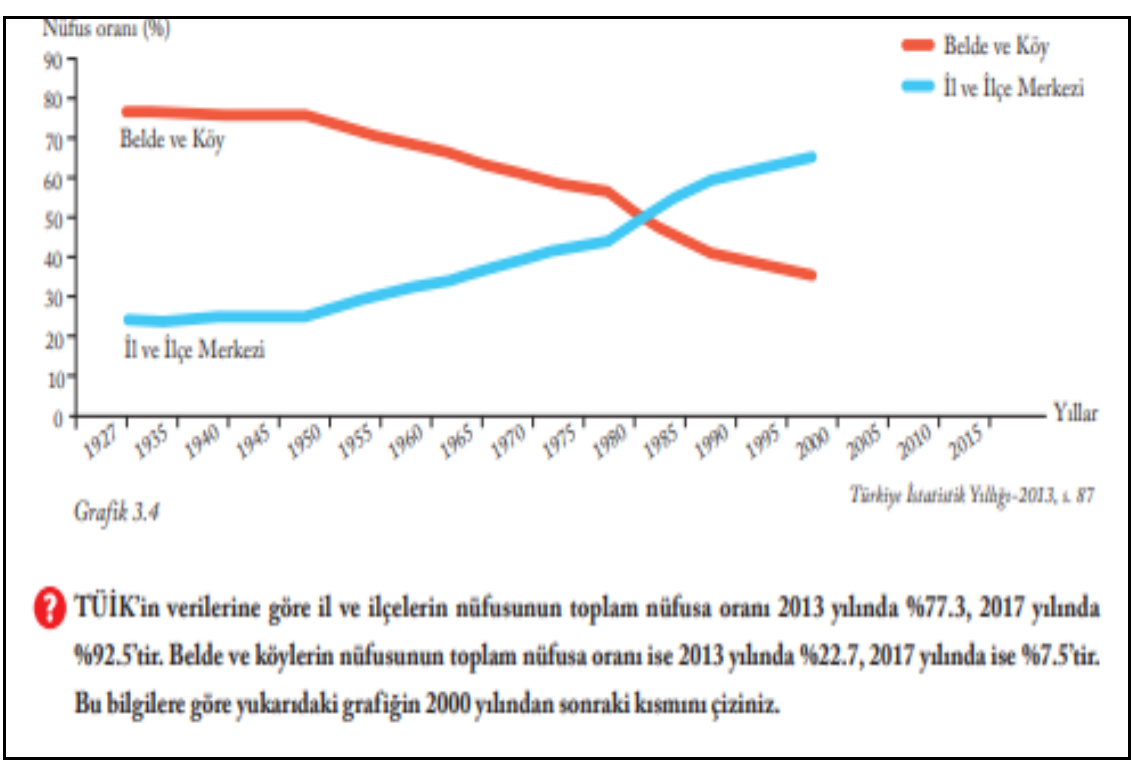

Şekil 10. B3.3ÖA.E24 Kodlu Etkinlik (B3, s. 113)

B3 kodlu 7. sınıf sosyal bilgiler ders kitabının insanlar, yerler ve çevreler öğrenme alanında yer alan bu etkinlikte öğrencinin verilen bilgileri inceleyerek grafiğin devamını çizmesi istenmiştir. Bir işlemi yerine getirme, yapma, yararlanma becerilerini geliştirmeyi hedefleyen bu etkinlik YBT'nin bilişsel süreç basamaklarından uygulama basamağına yerleştirilmiştir.

Etkinlik Kodu: B3.5ÖA.E16

Bilişsel Süreç Basamağı: Çözümleme

\section{Etkinlik Zamanı}

Aşağıdaki cümleleri uygun ifadelerle tamamlayınız.

Üretim teknolojilerindeki gelişmeler sayesinde daha fazla alan ekilebilir hâle geldi. Bunun sonucunda

Üretim teknolojilerindeki gelişmeler sayesinde insan gücüne duyulan ihtiyaç azaldı. Bunun sonucunda

Ưretim teknolojilerindeki gelişmeler sayesinde yilın her mevsimi ürün elde edilebilir oldu. Bunun sonucunda

Şekil 11. B3.5ÖA.E16 Kodlu Etkinlik (B3, s. 160)

B3 kodlu 7. sınıf sosyal bilgiler ders kitabında yer alan bu etkinlikte, öğrenciden verilen bilgilerin devamını getirmesi, olayların neden ve sonuçları arasındaki ilişkiyi kurması beklenmektedir. Etkinliğin verilen bir olayı detaylandırıp, olaylar arasında bağ kurma becerisini geliştirmeyi hedefleyen çözümleme bilişsel süreç basamağına ait olduğuna karar verilmiştir. 


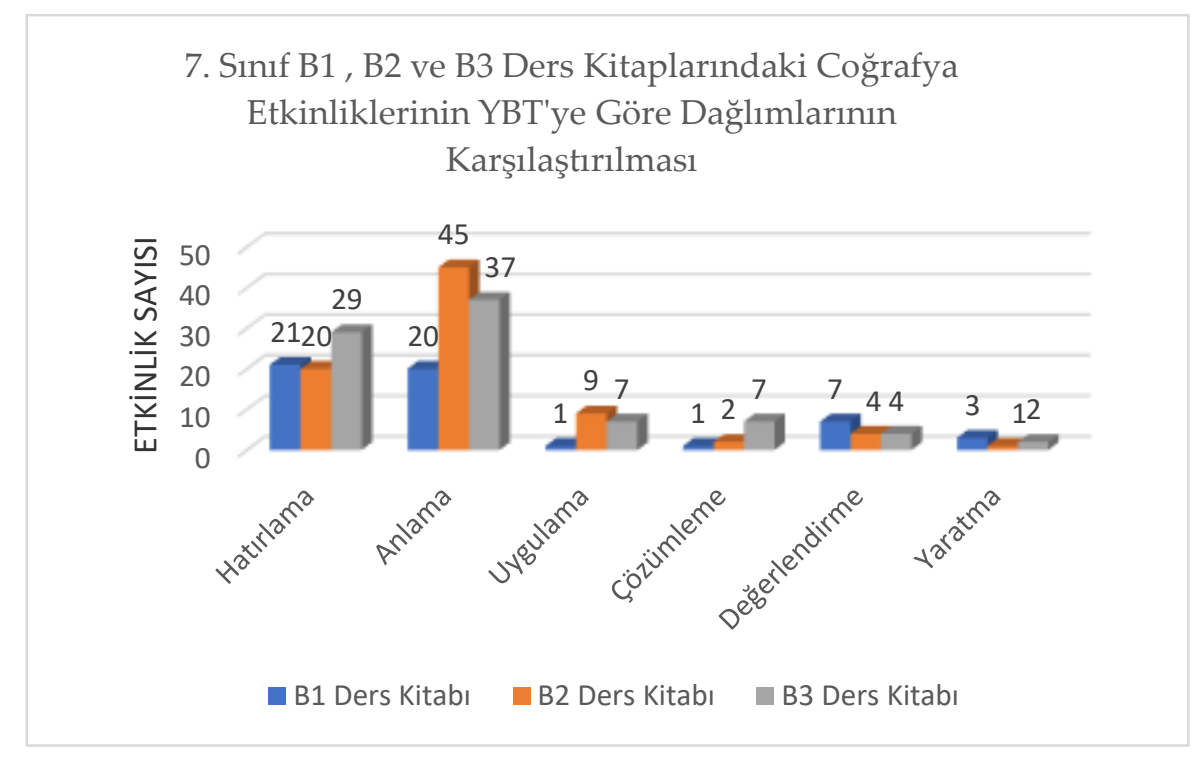

Şekil 12. B1, B2 ve B3 Ders Kitaplarındaki Coğrafya Etkinliklerinin YBT’ye Göre Dağılımlarının Karşılaştırılması

Araştırma kapsamında incelenen beş adet sosyal bilgiler ders kitabında yer alan 340 coğrafya etkinliğinin YBT'nin bilişsel süreç basamaklarına dağılımı Şekil 13'te verilmiştir.

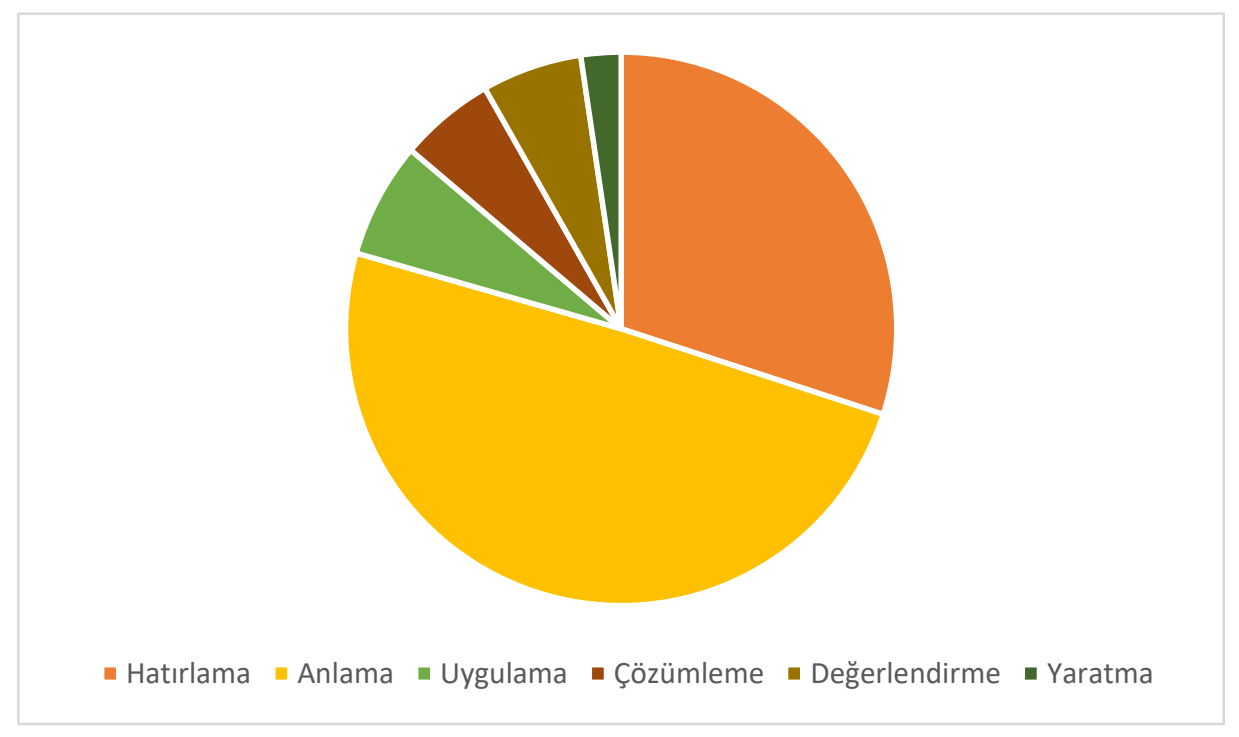

Şekil 13.A1, A2, B1, B2 ve B3 Ders Kitaplarındaki Coğrafya Etkinliklerinin YBT'nin Bilişsel Süreç Basamaklarına Göre Dağılımını Gösteren Grafik

\section{Sonuç}

Bu çalışmada 6. ve 7. sınıf sosyal bilgiler ders kitaplarında yer alan coğrafya etkinliklerinin Yenilenmiş Bloom Taksonomisi'ndeki bilişsel süreç boyutları incelenmiştir. Araştırmanın veri kaynaklarını 2019 Aralık ayında yayımlanan Tebliğler Dergisinde, 6. sınıflara ait 2 adet, 7. sınıflara ait 
3 adet sosyal bilgiler ders kitabı oluşturmaktadır. Ders kitaplarında yer alan 340 coğrafya etkinliğinin YBT'nin bilişsel süreç basamaklarına göre dağılımları yapılmıştır.

İncelenen ders kitaplarında yer alan 340 coğrafya etkinliğinin "Kültür ve Miras”, "İnsanlar, Yerler ve Çevreler", "Üretim, Dağıtım ve Tüketim”, "Küresel Bağlantılar" öğrenme alanlarında yer aldığı görülmüştür.

6. sınıflara ait iki ders kitabı incelendiğinde en çok etkinliğin $\mathrm{MEB}^{\prime} \mathrm{e}$ ait ders kitabında olduğu tespit edilmiştir. Ancak MEB'e ait ders kitabında üst düzey düşünme becerilerinin özel yayınevine ait ders kitabına nazaran daha az olduğu görülmüştür. Ayrıca A1 kodlu MEB 6. sınıf ders kitabında değerlendirme basamağına yönelik etkinliğin olmaması dikkat çekmektedir. Özel yayınevi olan Anadol Yayıncılık'a ait 6. sınıf ders kitabında YBT'nin her bilişsel seviyesine karşılık gelen etkinliğinin olduğu tespit edilmiştir. İki ders kitabında da alt düzey düşünme becerilerinin (hatırlama, anlama, uygulama) açık ara farkla daha çok olduğu sonucuna ulaşılmıştır.

7. sınıflara ait üç ders kitabı da incelendiğinde en az etkinliğin B1 kodlu MEB'e ait ders kitabında olduğu görülmektedir. B2 ve B3 kodlu ders kitaplarında etkinlik sayısı artmıştır. Bu sınıf düzeyinde de incelenen tüm kitaplarda alt düzey düşünme becerilerine yönelik coğrafya etkinlik sayısı yüksektir. Her üç ders kitabında da Yenilenmiş Bloom Taksonomisi'nin her bilişsel süreç basamağına göre etkinlikler bulunmaktadır.

İncelenen beş adet sosyal bilgiler ders kitabında 340 coğrafya etkinliğinin 102 tanesi hatırlama basamağında, 168 tanesi anlama basamağında, 23 tanesi uygulama basamağında, 19 tanesi çözümleme basamağında, 20 tanesi değerlendirme basamağında, 8 tanesi ise yaratma basamağında yer almaktadır. Alt düzey becerilere yönelik 293 coğrafya etkinliği varken üst düzey düşünme becerilerine ait toplam 47 coğrafya etkinliği olduğu sonucuna varılmıştır. 6. ve 7. sınıf sosyal bilgiler ders kitaplarında yer alan coğrafya etkinliklerinin genellikle hatırlama ve anlama basamağında olduğu görülmüştür. Öğrencinin yaratıcılığını geliştirmesine, bir soruna çözüm üretmesine, bir durum hakkındaki olayları analiz etmesine ve bu olayları değerlendirmesine yönelik becerilerin az olduğu görülmüştür.

Ders kitaplarında coğrafya konulu en fazla etkinliğin 86 adet etkinlikle B3 kodlu 7. sınıf sosyal bilgiler ders kitabı olan Ekoyay Yayıncılık'a ait olduğu görülmüştür. En az coğrafya etkinliği ise 52 etkinlikle A2 kodlu 6. sınıf Anadol Yayıncılık'a aittir. 7. sınıf ders kitaplarındaki coğrafya konulu etkinlik sayısı 6. sınıf ders kitaplarındaki coğrafya etkinliklerine göre daha yüksektir.

Yapılandırmacı yaklaşım gereği öğrencinin daha aktif olması beklenen derslerde bu tarz etkinlikler yapılarak program felsefesiyle ders işlenişinin uyuşmadığı sonucuna varılabilir. 2005 yılında değişen eğitim felsefesine yönelik Sosyal Bilgiler Dersi Öğretim Programı güncellenmiş, ders 
kitapları da bu değişimler ölçüsünde yenilenmiştir. Fakat araştırmadan elde edilen sonuçlara göre ders kitaplarında yer alan coğrafya etkinlikleri açısından bakıldığında öğrencinin aktif olabileceği kazanım ve etkinliklere fazla yer verilmediği görülmektedir.

\section{Tartışma}

Araştırmanın bu bölümünde, 2019 Aralık Tebliğler Dergisi'nde yayınlanan beş farklı sosyal bilgiler ders kitabındaki coğrafya etkinliklerine ait dokümanların incelenmesi sonucundan hareketle bu çalışmanın alanyazındaki çalışmalar ile karşılaştırılmasına ilişkin tartışmaya yer verilmiştir. Yapılandırmacı yaklaşımın benimsenmesiyle öğrencilerin eğitim öğretim ortamında aktif olup olmadığının sorgulanması, öğretim programlarındaki kazanımların benimsenen anlayışla ne derecede uyum sağladığı, etkinliklerin ne düzeyde gerçekleştirildiği ve öğrenci değerlendirme süreçlerinin işleyişi merak konusu olmuştur. Dersin işlenişinde önemli bir yere sahip olan etkinlikler, bazı çalışmalarda ele alınmıştır. İlköğretim programlarındaki etkinlikleri inceleyen Aykaç’a (2007) göre sosyal bilgiler programlarında yer alan etkinlikler genellikle öğretmen merkezli etkinliklerdir. Yapılandırmacı anlayışın hâkim olduğu eğitim anlayışımıza ait ders kitaplarında öğrencileri pasif konumda tutan etkinliklerin benimsenen anlayışa ters düştüğü söylenebilir. Ders kitaplarında yer alan etkinliklere yönelik yapılan çalışmalar bu görüşü destekler niteliktedir. Etkinliklerin düzensiz bir şekilde YBT'nin bilişsel beceri basamaklarına dağıldığı sonucuna ulaşan farklı disiplinlerden araştırmalar mevcuttur. Bu araştırmalarda alt düzey düşünme becerilerinin sürekli olarak öne çıtığ etkinliklerin öğrencinin son yıllarda vurgulanan yaratıcı düşünme, problemlere çözüm bulma gibi günümüzün önemli becerilerine ulaşmasını engelleyebileceği düşünülmektedir (Durukan ve Demir, 2017; Özkaral, 2019; Savaş, 2014; Ulum, 2017; Usluoğlu, 2020; Yılmaz, Akbaba, Halıpınar, Oral ve Ulusoy-Ünlü, 2021).

Birçok değerlendirme aşamasında kullanılan Yenilenmiş Bloom Taksonomisi, sınav sorularının sınıflandırılmasında da kullanılmıştır. Araştırmalarda elde edilen bulgulara göre soruların genellikle alt düzey becerilerine yönelik olduğu görülmüş, içlerinde en çok hatırlama ve anlama basamaklarına yer verildiği kanaatine varılmıştır. Öğretmenlerin genellikle ezbere yönelik sorular sorduğu belirlenmiş̧tir. Branşların değişmesine rağmen tutumun değişmediği; ölçme ve değerlendirme etkinliklerinde de alt düzey basamaklara olan alışkanlığın sürdürüldüğü görülmüştür (Ar1 ve İnci, 2015; Arseven, Şimşek ve Güden, 2016; Ayvacı ve Türkdoğan, 2010). Oran ve Karalı (2019) ile Yılmaz ve Gazel'in (2017) yaptığı değerlendirme sorularının Orijinal Bloom Taksonomisi'ne göre incelendiği çalışmalarda da benzer sonuçlara ulaşılmış ve alt düzey düşünme becerilerine yönelik değerlendirme sorularının daha fazla olduğu görülmüştür. 
Yapılan alanyazın araştırmasında ders disiplinleri ve incelenen veri kaynakları farklı olsa da bu çalışmalardaki bulgular genel olarak uyumludur. Bu durum öğretim programlarımızın her disiplin için belirli dönemlerde güncellenmiş olmasına rağmen etkinlik açısından beklenen seviyeye gelmediğini gösterebilir. Genellikle öğrencilerin alt düzey öğrenme becerilerine yönelik yazılmış kazanımlar ve bu kazanımlar doğrultusunda hazırlanmış ders kitabı etkinlikleri, ders kitabı değerlendirme soruları ile yazılı sınav soruları olduğu görülmektedir.

\section{Öneriler}

Ulaşılan bu sonuçlardan hareketle ders kitabı yazarlarına ve araştırmacılara şu önerilerde bulunulabilir:

1. Ders kitaplarındaki etkinlikler yazılırken coğrafya dersini ezbere dayalı kılan ve sadece bilgiyi hatırlama, belleğinden çağırma gibi düzeyleri kapsama yerine, çözümleme, değerlendirme, yaratma gibi öğrencilerin kendini geliştirebilmelerine olanak sağlayan üst düzey düşünme becerilerine yönelik olması, benimsenen eğitim felsefesini de temele alma bakımından daha anlamlı olabilir.

2. Ders kitaplarındaki etkinliklerin YBT üst düzey bilişsel basamaklardaki becerilerin gelişmesindeki rolüne vurgu yapılarak bu konu hakkında farklı ölçütler kullanılan araştırmalar yapılabilir.

\section{Kaynaklar}

Aç1l, Ö., Güvenç, H., Hayta, A. \& Kılıç, S. (2019). Ortaokul ve imam hatip ortaokulu 7. sınıf sosyal bilgiler ders kitabı. Ankara: MEB Yayınları, [e-kitap sürümü]. https://ders.eba.gov.tr/ders/proxy/ VCollabPlayerv0.0.816/index.html\#/main/dashboard/3/1/0 sayfasından erişilmiştir.

Altun, A. (2013). Yapılandırmacı yaklaşım, sosyal bilgiler programları ve ders kitapları. B. Akbaba (Ed.), Konu alanı ders kitabı inceleme kılavuzu sosyal bilgiler içinde (s. 1-28). Ankara: Pegem Akademi.

Anderson, L. W., Krathwohl, D. R., Airasian, P. W., Cruikshank, K. A., Mayer, R. E., Pintrich, P. R., ... \& Wittrock, M. C. (2018). Öğrenme öğretim ve değgerlendirme ile ilgili bir sinıflama: Bloom'un eğitimin hedefleri ile ilgili sınıflamasının güncelleştirilmiş biçimi (D. A. Özçelik, Çev., 3. b.). Ankara: Pegem Akademi.

Arı, A. (2013). Bilişsel alan sınıflamasında yenilenmiş Bloom, SOLO, Fink, Dettmer taksonomileri ve uluslararası alanda tanınma durumları. Uşak Üniversitesi Sosyal Bilimler Dergisi, 6(2), 259-290. doi: $10.12780 /$ UUSBD164 
Arı, A. \& İnci, T. (2015). Sekizinci sınıf fen ve teknoloji dersine ilişkin ortak sınav sorularının değerlendirilmesi. Uşak Üniversitesi Sosyal Bilimler Dergisi, 8(4), 17-50. https://dergipark.org.tr/ tr/pub/usaksosbil/issue/21661/232896 sayfasından erişilmiştir.

Arseven, A., Şimşek, U. \& Güden, M. (2016). Coğrafya dersi yazılı sınav sorularının yenilenmiş Bloom Taksonomisi'ne göre analizi. Cumhuriyet Üniversitesi Edebiyat Fakültesi Sosyal Bilimler Dergisi, 40(1), 243-258. https://dergipark.org.tr/tr/pub/cumusosbil/issue/24366/258293 sayfasindan erişilmiştir.

Artvinli, E. \& Dönmez, L. (2020). Value of responsibility and the attainments connection in 2018 social studies curriculum of Turkey. Osmangazi Journal of Educational Research, 7(2), 77-104. https://dergipark.org.tr/tr/pub/ojer/issue/57975/793986 sayfasından erişilmiştir.

Artvinli, E. (2010). Coğrafya derslerini yapılandırmak: Aksiyon (eylem) araştırmasına dayalı bir ders tasarımı. Marmara Coğrafya Dergisi, 21, 184-218. https://dergipark.org.tr/tr/pub/marucog/issue/ $\underline{468 / 3782}$ sayfasından alınmıştır.

Aykaç, N. (2007). İlköğretim programında yer alan etkinliklerin öğretmen görüşleri doğrultusunda değerlendirilmesi Sinop ili örneği. Ahi Evran Üniversitesi Kırşehir Eğitim Fakültesi Dergisi, 8(2), 19-35. https://dergipark.org.tr/tr/pub/kefad/issue/59527/856055 sayfasından alınmıştır.

Ayvacı, H. Ş. \& Türkdoğan, A. (2010). Yeniden yapılandırılan Bloom Taksonomisine göre fen ve teknoloji dersi yazılı sorularının incelenmesi. Journal of Turkish Science Education, 7(1), 13-25.

Azer, H. (2019). Ortaokul ve imam hatip ortaokulu 7. sımı sosyal bilgiler ders kitabı. Ankara: Ekoyay Eğitim Yayıncılık, [e-kitap sürümü]. https://ders.eba.gov.tr/ders/proxy/VCollabPlayer v0.0.816/ index.html\#/main/dashboard/3/1/0 adresinden erişilmiştir.

Beyreli, L. \& Sönmez, H. (2017). Bloom taksonomisi ve yenilenmiş Bloom taksonomisi ile ilgili Türkiye'de yapılan çalışmaların odaklandığı araştırma konuları. International Journal of Languages' Education and Teaching, 5(2), 213-229.

Bümen, N. T. (2006). Program geliştirmede bir dönüm noktası: Yenilenmiş Bloom Taksonomisi. Eğitim ve Bilim, 31(142), 3-14.

Can, Ş. \& Ekim, A. G. (2020). 6. sınıf fen bilimleri ders kitabında bulunan etkinliklerin fen öğretim programındaki hedef ve kazanımlarla ilişkisinin ve yeterliliğinin incelenmesi. Akdeniz Eğitim Araştırmaları Dergisi, 14(32), 249-265.

Çevik, A. \& Güneş, F. (2017). Türkçe ders kitaplarındaki etkinliklerin incelenmesi. Ana Dili Eğitimi Dergisi, 5(2), 272-286. doi: 10.16916/aded.288848 
Doğan, Y. \& Torun, F. (2018). Sosyal bilgiler ders kitapları nereye doğru gidiyor? The Journal of International Lingual Social and Educational Sciences, 4(2), 111-125. doi: 10.34137/jilses.491670

Durukan, E. \& Demir, E. (2017). 6, 7 ve 8. sınıf Türkçe dersi öğrenci çalışma kitaplarındaki etkinliklerin Bloom'un Yenilenmiş Taksonomisine göre sınıflandırılması. Uluslararası Türkçe Edebiyat Kültür Ĕ̆itim Dergisi, 6(3), 1619-1629.

Ersoy, F. \& Şahin, T. (2012). Examination of social studies textbooks in terms of approaches of values education. Educational Sciences: Theory \& Practice, 12(2), 1547-1558.

Göçer, A. (2008). İlköğretim Türkçe ders kitaplarının ölçme ve değerlendirme açısından incelenmesi. Atatürk Üniversitesi Sosyal Bilimler Enstitüsü Dergisi, 11(1), 197-210.

Gültekin, G., Akpınar, M., Nohutcu, M., Özerdoğan, P. \& Aygün, S. (2019). Ortaokul ve imam hatip ortaokulu 7. sınıf sosyal bilgiler ders kitabı. Ankara: MEB Yayınları, [e-kitap sürümü]. https://ders.eba.gov.tr/ders/proxy/ VCollabPlayer v0.0.816/index.html\#/main/dashboard/3/1/0 sayfasından alınmıştır.

Kabapınar, Y. (2019). Kuramdan uygulamaya hayat bilgisi ve sosyal bilgiler öğretimi: Hayat bilgisi öğretiminden tarih öğretimine. Ankara: Pegem Akademi.

Karataş, Z. (2015). Sosyal bilimlerde nitel araştırma yöntemleri. Manevi Temelli Sosyal Hizmet Araştırmaları Dergisi, 1(1), 62-80.

Krathwohl, D. R. (2002). A revision of Bloom's Taxonomy: An overview. Theory into Practies, 41(4), 212-218.

Ocak, G. \& Yurtseven, R. (2009). Beşinci sınıf sosyal bilgiler ders kitaplarının yapılandırmacı öğrenme yaklaşımına göre değerlendirilmesi. Balıkesir Üniversitesi Sosyal Bilimler Enstitüsü Dergisi, 12(22), 94-109. https://dergipark.org.tr/tr/pub/baunsobed/issue/50240/648090 sayfasindan alınmıştır.

Oran, M. \& Karalı, M. A. (2019). Ortaokul 7. sınıf sosyal bilgiler ders kitabı değerlendirme sorunlarının Bloom Taksonomisinde bilişsel alan basamaklarına göre incelenmesi. Uşak Üniversitesi Eğitim Araştırmaları Dergisi, 5(3), 88-104. doi: 10.29065/usakead.635309

Önal, H. \& Kaya, N. (2006). Sosyal bilgiler ders kitaplarının 4 ve 5. sınıf değerlendirilmesi. Balıkesir Üniversitesi Sosyal Bilimler Enstitüsü Dergisi, 9(16), 21-37. https://dergipark.org.tr/tr/pub/ baunsobed/issue/50334/651802 sayfasından erişilmiştir.

Özdemir, S. M., Altıok, S. \& Baki, N. (2015). Bloom'un Yenilenmiş Taksonomisine göre sosyal bilgiler öğretim programı kazanımlarının incelenmesi. Eğitim ve Öğretim Araştırmaları Dergisi, 4(3), 363-375. 
Özkaral, T. C. (2019, Ekim). 7. sınıf sosyal bilgiler ders kitabında yer alan soruların üst düzey düşünme becerileri açısından değerlendirilmesi. II. Uluslararası Coğrafya Eğitimi Kongresi Bildirileri içinde (s. 219-225). Eskişehir Osmangazi Üniversitesi, Eskişehir.

Savaş, Ö. (2014). Ortaokul Türkçe ders kitaplarındaki dinleme etkinliklerinin güncelleştirilmiş Bloom sınıflamasına göre üst düzey bilişsel beceriler açısından değerlendirilmesi. (Yüksek Lisans Tezi). http://tez.yok.gov.tr sayfasından erişilmiştir.

Şahin, E. (2019). Ortaokul ve imam hatip ortaokulu 6. sınıf sosyal bilgiler ders kitabı. Ankara: Anadol.

Ulum, H. (2017). MEB ilkokul 2, 3 ve 4. sınıf Türkçe ders ve çalı̧̧ma kitaplarında yer alan etkinliklerin Yenilenmiş Bloom Taksonomisine göre incelenmesi. (Yüksek Lisans Tezi). http://tez.yok.gov.tr sayfasından erişilmiştir.

Usluoğlu, B. (2020). İlkokul 3 ve 4. sınıf matematik ders kitaplarındaki etkinliklerin yenilenmiş Bloom taksonomisine göre incelenmesi. (Yüksek Lisans Tezi). http://tez.yok.gov.tr sayfasından erişilmiştir.

Wilson, L. O. (2001). Anderson and Krathwohl Bloom's Taxonomy Revised understanding the new version of Bloom's taxonomy. https:/quincycollege.edu/wp-content/uploads/Anderson-andKrathwohl Revised-Blooms-Taxonomy.pdf sayfasından erişilmiştir.

Yıldırım, A. \& Şimşek, H. (2018). Sosyal bilimlerde nitel araştırma yöntemleri. Ankara: Seçkin.

Yıldırım, C., Kaplan, F., Kuru, H. \& Yılmaz, M. (2019). Ortaokul ve imam hatip ortaokulu 6. sinnf sosyal bilgiler ders kitabı. Ankara: MEB Yayınları, [e-kitap sürümü]. https://ders.eba.gov.tr/ders/proxy/ VCollabPlayerv0.0.828/index.html\#/main/dashboard/3/1/0 sayfasından erişilmiştir.

Yılmaz, A. A. \& Gazel, A. (2017). Yeniden yapılandırılan Bloom Taksonomisine göre fen ve teknoloji dersi yazılı sorularının incelenmesi. Afyon Kocatepe Üniversitesi Sosyal Bilimler Dergisi, 19(2), 173-186.

Yılmaz, A., Akbaba, F. D., Halıpınar, F. M., Oral, S. \& Ulusoy-Ünlü, A. (2021). Okul öncesi eğitim etkinlik kitabının Yenilenmiş Bloom Taksonomisine göre incelenmesi. Uludă̆ Üniversitesi Ĕ̆itim Fakültesi Dergisi, 34(1), 343-385.

\section{Extended Summary}

Textbooks, which are one of the most used teaching materials in learning environments, are expected to catch up with the education understanding of the age. The importance of the textbook is great as it is the most easily accessible material for students. The textbooks, which include the information that the student needs to learn, the activities that will improve the individual, and the evaluation questions prepared to determine what and how much they have learned, are in the nature 
of a guide for education. Textbooks are of great importance for the society as they reach every part of the society without distinguishing socio-economic and cultural differences.

The Republic of Turkey Ministry of National Education has carried out studies on the preparation of textbooks according to the constructivist approach and the changing social studies curriculum, and changes have occurred in the textbooks in this direction. Long phrases that present information directly and are full of definitions are not included.

In the light of the above explanations, this research aimed to answer this main problem: how is the analysis of geography activities in social studies textbooks according to the cognitive process level of the Revised Bloom's Revised Taxonomy? It is structured according to this problem statement. The purpose of this question is to analyze the geography activities in the 6th and 7th grade Social Studies textbooks according to the cognitive process level of the Revised Bloom Taxonomy and compare them with taxonomic levels. In order to analyze the taxonomic level of geography activities in secondary school social studies textbooks, the following sub-problems are sought to be answered in the research:

1. How is the distribution of the geography activities in the 6th grade social studies textbooks to the cognitive process dimension steps of the Revised Bloom Taxonomy and their relationship with the achievements?

2. How is the distribution of the geography activities in the 7th grade social studies textbooks to the cognitive process dimension steps of the Revised Bloom Taxonomy and their relationship with the achievements?

In this study, the cognitive process dimensions of the geography activities in the 6th and 7th grade social studies textbooks in the Revised Bloom Taxonomy (RBT) were examined. The data sources of the research were published in the Journal of Announcements published in December 2019; it consists of 3 social studies textbooks belonging to 7 th graders. When the two textbooks belonging to 6th graders were examined, it was determined that the most activities were in the textbook belonging to the Ministry of National Education. However, it has been observed that high-level thinking skills in the textbook belonging to the Ministry of National Education are less than the textbook belonging to a private publishing house. In addition, it is noteworthy that there is no activity for the evaluation step in the A1 coded MEB 6th grade textbook. It has been determined that the 6th grade textbook of Anadol Publishing, a private publishing house, has an activity corresponding to each cognitive level of RBT. In both textbooks, it was concluded that low-level thinking skills (remembering, understanding, and applying) were higher by far. 
The distribution of 340 geography activities in the textbooks was made according to the cognitive process step of RBT. It has been observed that 340 geography activities in the examined textbooks take place in the learning areas of culture and heritage, people, places and environments, production, distribution and consumption, and global connections. It can be concluded that the curriculum philosophy and the teaching of the course do not match by doing such activities in the courses where the student is expected to be more active due to the constructivist approach. In the five social studies textbooks examined, 102 of the 340 geography activities are at the remembering level, 168 at the comprehension level, 23 at the application level, 19 at the analysis level, 20 at the evaluation level, and 8 at the creation level. It was concluded that while there were 293 geography activities for low-level skills, there were a total of 47 geography activities for high-level thinking skills. It has been observed that the geography activities in the 6th and 7th grade social studies textbooks are generally at the remembering and understanding level. It has been observed that the skills for developing the creativity of the student, producing a solution to a problem, analyzing the events about a situation, and evaluating these events are low. The Social Studies Curriculum for the changing educational philosophy in 2005 was updated both in 2005 and 2018; textbooks were also renewed in line with these changes. However, according to the results obtained from the research, when we look at the geography activities in the textbooks, it is seen that the acquisitions and activities in which the student can be active are not given much space. With the adoption of the constructivist approach, the questioning of whether the students are active in the education environment, to what extent the achievements in the curriculum comply with the adopted understanding, to what extent the activities are carried out, and the functioning of the student evaluation processes have been a matter of curiosity. The activities, which have an important place in the teaching of the course, have been discussed in some studies.

Although the disciplines of the course and the data sources examined in the literature research are different, the findings in these studies are generally compatible. This may show that although our curricula have been updated in certain periods for each discipline, they have not reached the expected level in terms of effectiveness. Generally, it is seen that there are achievements written for low-level thinking skills and textbook activities prepared in line with these achievements, textbook evaluation questions, and written exam questions.

Based on these results, the following suggestions can be made to textbook authors and researchers: While writing the textbooks, such a taxonomic analysis of the achievements by the authors and determining their levels can help to create the activities to be included in the books according to the correct attainment levels. Thus, there will be an opportunity to write more textbooks 
suitable for the program. While writing the activities in the textbooks, it may be more meaningful in terms of taking the adopted education philosophy as a basis, instead of making the geography lesson based on rote memorization and not only covering the levels such as remembering information and recalling it from memory, but also focusing on high-level thinking skills that allow students to develop themselves such as analysis, synthesis, and evaluation. By emphasizing the role of the activities in the textbooks in the development of skills in the higher cognitive levels of RBT, research can be conducted using different criteria on this subject.

\section{Ekler}

Ek1. Etkinliklerin YBT’nin Bilişsel Süreç Basamaklarına Göre Sınıflandırılmasında Yararlanılan Anahtar Tablo

\begin{tabular}{|c|c|c|}
\hline Basamaklar & Özellikler & Beceriler \\
\hline $\begin{array}{l}\text { Hatırlama } \\
\text { Tanıma } \\
\text { Anımsama }\end{array}$ & $\begin{array}{c}\text { Bilgiyi Uzun Süreli Bellekten Geri } \\
\text { Getirme }\end{array}$ & $\begin{array}{c}\text { Hatırlama } \\
\text { Tanımlamak } \\
\text { Listelemek } \\
\text { İfade Etmek } \\
\text { Eşleştirmek } \\
\text { Ezberlemek } \\
\text { Bire Bir Saymak }\end{array}$ \\
\hline $\begin{array}{l}\text { Anlama } \\
\text { Yorumlama } \\
\text { Açılama } \\
\text { Örnekleme } \\
\text { Sinıflama } \\
\text { Sonuç Çıkarma } \\
\text { İlişkilendirme }\end{array}$ & $\begin{array}{l}\text { Önceki Bilgilerden Hareketle Anlam } \\
\text { Çıkarma }\end{array}$ & $\begin{array}{c}\text { Düzenlemek } \\
\text { Ayrıntılı Tanımlamak } \\
\text { Farklı Sözcüklerle İfade Etmek } \\
\text { Örneklendirmek } \\
\text { Tespit Etmek } \\
\text { Tartışmak } \\
\text { Yorumlamak } \\
\text { Özetlemek } \\
\text { Çeviri Yapmak } \\
\end{array}$ \\
\hline $\begin{array}{l}\text { Uygulama } \\
\text { Yapma } \\
\text { Yararlanma }\end{array}$ & $\begin{array}{l}\text { Verilen Bir Duruma Göre İşlem } \\
\text { Yapma veya Ondan Yararlanma }\end{array}$ & $\begin{array}{c}\text { Hesaplamak } \\
\text { Çalıştırmak } \\
\text { Çözmek } \\
\text { Kullanmak } \\
\text { Üzerinde Değişiklik Yapmak } \\
\text { Meydana Getirmek } \\
\text { Tahmin Yürütmek } \\
\text { Geliştirmek } \\
\end{array}$ \\
\hline $\begin{array}{l}\text { Çözümleme } \\
\text { Ayrıştırma } \\
\text { Örgütleme } \\
\text { İrdeleme }\end{array}$ & $\begin{array}{c}\text { Bir Bütünü Parçalara Ayırma, } \\
\text { Parçaların Birbiriyle ve Materyalin } \\
\text { Bütünüyle İçinde Olduğu İlişkiyi } \\
\text { Belirleme }\end{array}$ & $\begin{array}{c}\text { Ayırt Etmek } \\
\text { Sorgulamak } \\
\text { Muhasebesini Yapmak } \\
\text { Karşılaştırmak } \\
\text { Kategorilere Ayırmak } \\
\text { Çözüme Ulaşmak } \\
\text { Tartışmak } \\
\end{array}$ \\
\hline $\begin{array}{l}\text { Değerlendirme } \\
\text { Denetleme } \\
\text { Eleştirme }\end{array}$ & $\begin{array}{l}\text { Belirli Bir Ölçüt Dahilinde Olay veya } \\
\text { Materyaller Hakkında Sonuca Varma }\end{array}$ & $\begin{array}{c}\text { Test Etmek } \\
\text { Yargilamak } \\
\text { Karara Varmak } \\
\text { Öneride Bulunmak } \\
\text { Hipotez Oluşturmak } \\
\text { Kontrol Etmek }\end{array}$ \\
\hline $\begin{array}{l}\text { Yaratma } \\
\text { Oluşturma } \\
\text { Planlama } \\
\text { Üretme }\end{array}$ & $\begin{array}{c}\text { Bir Düzen İçerisinde İşlevsel Bir Yapı } \\
\text { Meydana Getirme }\end{array}$ & $\begin{array}{l}\text { Yapılandırmak } \\
\text { Dönüştürmek } \\
\text { Yaratmak } \\
\text { Geliștirmek }\end{array}$ \\
\hline
\end{tabular}


Tasarlamak Ortak Çalışmak

Dizayn Etmek

Modelini Yapmak Müzakere Etmek

(Anderson vd. 2018; Arı, 2013; Ulum, 2017).

\section{Araştırmacıların Katkı Oranı Beyanı}

Bu çalışmaya birinci yazar \%60 oranında, ikinci yazar \%40 oranında katkı sağlamıştır.

\section{Destek ve Teşekkür Beyanı}

$\mathrm{Bu}$ araştırmada herhangi bir kurum, kuruluş ya da kişiden destek alınmamıştır.

\section{Çatışma Beyanı}

Araştırmacıların araştırma ile ilgili diğer kişi ve kurumlarla herhangi bir kişisel ve finansal çıkar çatışması yoktur.

\section{Etik Kurul Beyanı}

$\mathrm{Bu}$ araştırma, doküman incelemesi yapılarak yürütüldüğünden etik kurul onayı gerektirmemektedir. 